NBER WORKING PAPER SERIES

\title{
USING A HEDONIC MODEL OF SOLAR RADIATION TO ASSESS THE ECONOMIC EFFECT OF CLIMATE CHANGE: THE CASE OF MOSEL VALLEY VINEYARDS
}

\author{
Orley Ashenfelter \\ Karl Storchmann \\ Working Paper 12380 \\ http://www.nber.org/papers/w12380
NATIONAL BUREAU OF ECONOMIC RESEARCH
1050 Massachusetts Avenue
Cambridge, MA 02138
July 2006

The views expressed herein are those of the author(s) and do not necessarily reflect the views of the National Bureau of Economic Research.

(C2006 by Orley Ashenfelter and Karl Storchmann. All rights reserved. Short sections of text, not to exceed two paragraphs, may be quoted without explicit permission provided that full credit, including (C) notice, is given to the source. 
Using a Hedonic Model of Solar Radiation to Assess the Economic Effect of Climate Change:

The Case of Mosel Valley Vineyards

Orley Ashenfelter and Karl Storchmann

NBER Working Paper No. 12380

July 2006

JEL No. C2, Q5

\begin{abstract}
In this paper we provide a simple, credible method for assessing the effects of climate change on the quality of agricultural land and then apply this method using a rich set of data on the vineyards of the Mosel Valley in Germany. The basic idea is to use a simple model of solar radiation to measure the amount of energy collected by a vineyard, and then to establish the econometric relation between energy and vineyard quality. Coupling this hedonic function with the elementary physics of heat and energy permits a straightforward calculation of the impact of any climate change on vineyard quality (and prices). We show that the variability in vineyard quality in this region is due primarily to the extent to which each vineyard is able to capture radiant solar energy, so that these data provide a particularly credible "experiment" for identifying and measuring the appropriate hedonic equation.

Our empirical results indicate that the vineyards of the Mosel Valley will increase in value under a scenario of global warming, and perhaps by a considerable amount. Vineyard and grape prices increase more than proportionally with greater ripeness, so that we estimate a $3^{\circ} \mathrm{C}$ increase in temperature would more than double the value of this vineyard area, while a $1^{\circ} \mathrm{C}$ increase would increase prices by about 20 percent.
\end{abstract}

Orley C. Ashenfelter

Industrial Relations Section

Firestone Library

Princeton University

Princeton, NJ 08544

and NBER

c6789@princeton.edu 


\title{
Using a Hedonic Model of Solar Radiation to Assess the Economic Effect of Climate Change: The Case of Mosel Valley Vineyards
}

\author{
Orley Ashenfelter \\ Princeton University \\ and \\ Karl Storchmann \\ Whitman College \\ June 2006
}

\begin{abstract}
In this paper we provide a simple, credible method for assessing the effects of climate change on the quality of agricultural land and then apply this method using a rich set of data on the vineyards of the Mosel Valley in Germany. The basic idea is to use a simple model of solar radiation to measure the amount of energy collected by a vineyard, and then to establish the econometric relation between energy and vineyard quality. Coupling this hedonic function with the elementary physics of heat and energy permits a straightforward calculation of the impact of any climate change on vineyard quality (and prices). We show that the variability in vineyard quality in this region is due primarily to the extent to which each vineyard is able to capture radiant solar energy, so that these data provide a particularly credible "experiment" for identifying and measuring the appropriate hedonic equation.

Our empirical results indicate that the vineyards of the Mosel Valley will increase in value under a scenario of global warming, and perhaps by a considerable amount. Vineyard and grape prices increase more than proportionally with greater ripeness, so that we estimate a $3^{\circ} \mathrm{C}$ increase in temperature would more than double the value of this vineyard area, while a $1{ }^{\circ} \mathrm{C}$ increase would increase prices by about 20 percent.
\end{abstract}

\section{Introduction}

In this paper we provide a simple, credible method for assessing the effects of climate change on the quality of agricultural land and then apply this method using a rich set of data on the vineyards of the Mosel Valley in Germany. The basic idea is to use a simple model of solar radiation to measure the amount of energy collected by a vineyard, and then to establish the econometric relation between energy and vineyard quality. Coupling this hedonic function with the elementary physics of heat and energy permits a straightforward calculation of the impact of any climate change on vineyard quality (and prices). Although we show that this approach can, in principle, be applied to any crop grown on any land, the vineyards of the Mosel are a particularly attractive place to assess this method for measuring the effect that 
expected climate changes may have on quality and relative prices. Since the vineyards of this Valley are situated near the far northern boundary feasible for grape production, they differ enormously in their suitability for grape growing. We show that this variability is due primarily to the extent to which each vineyard is able to capture radiant solar energy, so that these data provide a particularly credible "experiment" for identifying and measuring the appropriate hedonic equation.

Our approach follows and extends the so-called "Ricardian" approach applied by Mendelsohn, Nordhaus, and Shaw (1994) to the study of effects of climate change on agriculture. Their empirical research, based as it is on hedonic models from highly aggregated data, has been critiqued and extended to consider difficult issues of functional form and specification by Schlenker, Hanemann, and Fisher (2005) and (2006), and Deschenes and Greenstone (2006). These more recent studies generally find considerable heterogeneity in the expected effects of climate change. Depending on the region considered, climate change may lead to either positive or negative effects on land values, with considerable uncertainty about the aggregate effect. Our approach follows this more recent work by studying a very specific area and type of crop and by establishing the economic relation between solar radiation and farm quality for this crop type. Our approach has the advantage that it provides a detailed and credible sketch of precisely how global warming affects crop quality, which is at the heart of discussions of climate change. The disadvantage of our approach is that it provides only one component of an aggregate estimate of the overall effect of climate change.

Our empirical results indicate that the vineyards of the Mosel Valley will increase in value under a scenario of global warming, and perhaps by a considerable amount. Vineyard and grape prices increase more than proportionally with greater ripeness, so that we estimate a $3^{\circ} \mathrm{C}$ increase in temperature would more than double the value of this vineyard area, while a $1^{\circ} \mathrm{C}$ increase would increase prices by about 20 percent.

The paper is structured as follows: In Section 2 we explain how solar radiation is captured by a vineyard and how an energy value can be calculated for each vineyard site using the basic physics of solar panel construction. Section 3 discusses the data we use for the analysis, including the data on vineyard quality that we have constructed and the hedonic 
characteristics of the vineyards we study. In Section 4 we present the estimates of our hedonic model of vineyard site quality, while Section 5 contains our calculations of the impact of possible climate change on the quality distribution of vineyard sites. We summarize our findings in Section 6.

\section{Radiation Use Efficiency, Solar Panels, and Vineyards}

Commercial viticulture is found only between $35^{\circ}$ and $50^{\circ}$ latitude. Located between $49.61^{\circ}$ and $50.34^{0}$ latitude, the vineyards of Germany's Mosel region are thus at the cold limit for grape growing. As a result, all Mosel vineyards depend on special site characteristics to ensure winter survival and ripening (Gladstones, 1992). As we will show, with these growing conditions a good vineyard site must be, among other things, a natural solar panel, maximizing the incoming solar radiation with its angle of incidence and orientation.

\section{A. Radiation Use Efficiency}

Surprisingly, formal research on the influence of light on crop growth dates primarily from the late 1950s (DeWit, 1959). Some 20 years later Monteith (1977) provided the basis for calculating the quantitative relationship between intercepted solar radiation (energy) and the amount of dry biomass produced. This relationship is expressed by the term radiation use efficiency (RUE), and it measures the mass accumulation in gram dry matter per $\mathrm{MJ}^{-1} \mathrm{~m}^{-2}$ of intercepted solar radiation. It is this biomass that represents the economically valuable output of a plant.

Subsequent studies have estimated RUE for different crops (Sinclair and Muchow, 1999), and this research continues today. It is likely that the RUE is fairly similar for the members of a specific crop but varies significantly among crop species. As shown in Table 1, $\mathrm{C}_{4}$ species such as maize, sorghum, and sugarcane have significantly higher RUE than do the $\mathrm{C}_{3}$ species, such as potatoes, wheat, barley, rice, soybeans, and sunflowers. ${ }^{1}$ The only study of the RUE of grapevines (vitis vinifera) of which we are aware is for the Merlot variety (Castelan-Estrada, 2001). With an RUE between 0.57 and $0.70 \mathrm{~g} \mathrm{MJ}^{-1}$, this study indicates that, in terms of RUE, vitis vinifera belong to the least efficient plants. It follows that the

\footnotetext{
${ }^{1} \mathrm{C}_{4}$ crops produce less complicated nutrients, e.g. sugar and starch, whereas $\mathrm{C}_{3}$ crops produce more complex and higher quality nutrients like oil and protein.
} 
energy intensity of a particular site is far more important for grapevines than it is for wheat or cauliflower.

B. Vineyards as Solar Panels

Only a part of solar radiation reaches the surface of the earth directly (beam radiation). Another part is scattered by the atmosphere and reaches the surface as so-called diffuse radiation. The sum of both is referred to as total solar radiation. However, it is apparent that total solar radiation is highly dependent on the amount, kind and density of clouds, and varies with time and place. For the sake of simplicity engineers often calculate the so-called extraterrestrial radiation, that is, the radiation that would be available if there were no atmosphere (Duffie and Beckman, 1991). This is precisely the simplification we will use to construct a measure of the differences in solar radiation input provided by the different vineyards of the Mosel Valley. Since all these vineyards lie in a very small geographical region, we know that differences across vineyards in total radiation are due primarily to differences in site characteristics and not to differences in the weather.

Figure 1 shows the extraterrestrial radiation on a horizontal surface for different geographical latitudes in the northern hemisphere. It is apparent that there is a large difference in both the total amount of energy as well as its distribution over the year. While a plane at the equator receives the maximum energy amount of about $13.2 \mathrm{GJm}^{-2} \mathrm{a}^{-1}$, the incoming radiation decreases with increasing latitude. With an energy level of $9.1 \mathrm{GJm}^{-2} \mathrm{a}^{-1}$ the Mosel-SaarRuwer region obtains only $2 / 3$ of the total maximum energy amount. Moreover, whereas the energy flux at the equator is comparatively evenly distributed, the radiation pattern becomes increasingly focused on June 21 the further north one gets. Daily solar radiation in the north is often even greater in summer than that at equatorial latitudes because of the north's long summer days. As Figure 1 indicates, the farther north one goes, the less energy there is available during off-peak times in late spring and late summer. For instance, at the end of October, the main harvest time for Riesling grapes in the Mosel valley, there is only a photon flux of $13 \mathrm{MJm}^{-2} \mathrm{day}^{-1}$ compared to $37 \mathrm{MJm}^{-2} \mathrm{day}^{-1}$ at the equator, that is, only a third of the maximal achievable amount.

This energy deficit at high latitudes can be remedied by the right slope. Figure 2 shows the solar radiation for the Mosel city of Trier ( $49.8^{0}$ north) by inclination (assuming a 
southern orientation). Although a plane surface only receives $9.1 \mathrm{GJm}^{-2} \mathrm{a}^{-1}$ (as already shown in Figure 1) increasing inclination enhances the energy level significantly. A tilt of $45^{\circ}$ provides more than $40 \%$ more energy $\left(12.8 \mathrm{GJm}^{-2} \mathrm{a}^{-1}\right)$, and only $3 \%$ less than the maximum amount achievable at the equator. Moreover, the distribution over the year strikingly resembles that of the equator; the energy flow from March to October is almost the same. Hence, a vineyard's inclination can almost perfectly offset its unfavorable latitude. However, this does not mean that the steeper vineyards are always better. Vineyards that are tilted more than $45^{\circ}$ receive less energy than those with less inclination (at this latitude), and the energy received is also more unequally distributed over the course of the year. For example, an inclination of $95^{\circ}$ yields only slightly more solar radiation than a horizontal surface. The optimal inclination is dependent on the latitude: The farther north, the steeper the optimal site must be. With respect to the Mosel valley the optimal tilt is about $45^{\circ}$.

The calculations thus far are based on the assumption that the tilted vineyard has a southern orientation. Figure 3 shows the impact of a different orientation for the vineyard on solar energy, holding the latitude constant (at Trier's) and holding the inclination at its optimal level for this latitude, i.e., $45^{\circ}$. A southern aspect is the ideal, and with increasing deviation from a southern aspect the energy yield falls dramatically. If the tilted vineyard is west facing, the yearly solar radiation is less than on a horizontal surface ( 8.9 compared to 9.1 $\mathrm{GJm}^{-2} \mathrm{a}^{-1}$ given in Figure 2). A sloping vineyard with north-western aspect receives only 4.7 $\mathrm{GJm}^{-2} \mathrm{a}^{-1}$, less than a horizontal plane in the arctic circle. ${ }^{2}$

C. Calculation of Solar Radiation

Given data on the latitude $(\varphi)$, slope $(\beta)$, and orientation $(\gamma)$ for any vineyard or agricultural site we show in the Appendix how to calculate a single measure of solar radiation for each month of the year. We aggregated these monthly figures for the vineyards of the Mosel to obtain measures of solar radiation during both (a) the critical ripening period for grapes (September and October) and (b) the full year. These are the data we use in our hedonic analysis. ${ }^{3}$ Summary statistics of these measures are contained in the bottom two rows of Table 4. The data indicate remarkable variability among the vineyards. For example, the

\footnotetext{
${ }^{2}$ This raises the question of why there are steep vineyards with unfavorable orientations at all: The energy yield is lower than on a plane surface while the labor costs are considerably higher. It seems likely that these vineyard sites were selected for non-economic reasons, such as their nearness to a cloister.
} 
annual energy yield ranges from a high of $12.802 \mathrm{GJm}^{-2}$ to a low of $5.568 \mathrm{GJm}^{-2}$, or nearly a $130 \%$ difference. The total variability in our measure of solar radiation in the crucial ripening period for grapes is even greater and spans the range from $2.237 \mathrm{GJm}^{-2}$ to $0.695 \mathrm{GJm}^{-2}$, or nearly a $220 \%$ difference.

\section{Other Factors that Affect Vineyard Sites}

Gladstones (1992) provides a detailed analysis of several other factors that make specific geographic sites more or less suitable for the production of high quality grapes. Important factors include those that reduce diurnal (night-day) temperature differences. Nearness to a body of water and, especially, soil type are important determinants of diurnal fluctuations. Thus, the heat storage capacity and solar reflectivity (measured by its albedo number, $\alpha$ ) of some soils is of considerable potential importance in determining the quality of a vineyard site and we also measure these factors in the empirical analysis below.

\section{Data}

Our analysis makes use of data from two different sources on very specific vineyard sites. $^{4}$ Unfortunately the definition of these distinct vineyard sites has changed at times so that our two key sources are not based on precisely the same vineyard definitions. Stöhr et al. (1981) provide a comprehensive description of all the geographic characteristics of the MoselSaar-Ruwer vineyard sites as they were defined in $1971 .^{5}$ These data were taken as the baseline for our calculations. We supplemented these data on the geographic characteristics of the vineyards with measures of the historical prices of the vineyards based on taxation records, primarily from the $19^{\text {th }}$ century. Since the latter data were based on finer divisions of

\footnotetext{
${ }^{3}$ Detailed calculations for individual vineyards are available from the authors upon request.

${ }^{4}$ German vineyard sites have precise names to avoid duplication. A vineyard in the town of Berncastel is a "Berncasteler." The "Doctor" vineyard in the town of Berncastel is thus known as the "Berncasteler Doctor" to distinguish it from any other vineyard named "Doctor."

${ }^{5}$ The Mosel River is the largest tributary of the Rhine. The grape growing region known as the Mosel, which runs with the river roughly 206 kilometers northeast from Trier to Koblenz, actually consists of a system of river valleys that includes the tributaries the Saar and the Ruwer. Thus, the official term for this wine area is "MoselSaar-Ruwer.”
} 
vineyards, that is, smaller vineyard sites, we lose some information by aggregating to the 1971 benchmark. $^{6}$

A. Vineyard Price and Quality

The most difficult aspect of our data construction is the ranking by price of the respective vineyards. Prices of vineyard sites have been assessed for taxation purposes in the Mosel since the $17^{\text {th }}$ century. An early example of such a ranking that was made by the French, who controlled the Mosel area in the early part of the $19^{\text {th }}$ century, is contained in Table 2. A "repurchase price" was set for the wines of each vineyard, and this formed the basis for its taxation. However, we rely primarily on the work of the Prussian tax administration during the mid- $19^{\text {th }}$ century for our ranking of vineyards by price. Using the work started by the French, the Prussians completed a meticulously detailed land register in the 1830s in order to tax the land according to the value of its production. Using a method very similar to that used for the classification of Bordeaux wines in 1855 (Penning-Roswell, 1986; Markham, 1998), the value of vineyard sites was taken as proportional to the average prices for the wines of each vineyard over a 24 year period from 1837 to 1860 (Beck, 1869) ${ }^{7}$. The Prussian tax administration distinguished 8 different net yield grades, and in 1869, this ranking was published by the Government of the King of Prussia (Beck, 1869, 26-33). This list distinguishes between different vineyards within the various villages. To provide the detailed location of the vineyard sites the government also published a map of these sites for the administrative district of Trier, i.e., the upper Mosel, in 1868 (Clotten, 1868); and a similar map for the lower Mosel, i.e., for the district of Koblenz, in 1897 (Lintz, 1897).

We use these maps to construct a price-based ranking of the vineyards. Unfortunately the vineyard sites ranked by price in Beck (1869) are not necessarily identical to those used by Stöhr et al. (1981) to provide vineyard site characteristics. Accordingly, the maps of 1868 and 1897, respectively, as well as the maps provided by Stöhr et al., were used to apply the Prussian ranking to contemporary vineyard sites.

\footnotetext{
${ }^{6}$ For instance, in 1910 there were about 4550 defined vineyard sites within a demarcated area of 6,800 hectares (Goldschmidt, 1925). The German wine law of 1971 defines only 523 vineyard sites within an area of 11,985 hectares (Stöhr et al., 1981; Statistisches Bundesamt, 1998).

${ }^{7}$ In order to avoid distortions caused by differences in prices across different vintages the optimal estimation period and the appropriate computational method were discussed in great detail at the time (e.g., Lindauer, 1815; Flotow, 1820; Gebhard 1824, Schimmelfennig, 1831).
} 
The estimates we obtained were compared to the vineyard size figures published by the Prussian government (Beck, 1869). The comparison of these figures as well as the maps ensures a certain degree of consistency. In addition, any "new vineyards" that did not exist during the period of the 1869 ranking were excluded from the analysis. As a result, of the 523 currently recognized vineyards, only a total of 344 vineyard sites are included in our analysis. Finally, the results of our analysis were cross-checked with the "new" vineyard classification constructed by Stuart Pigott (1995), which is also based on the older Prussian ranking. Our ranking, like those before, distinguishes eight ordinal grades of vineyard quality, where rank one denotes the highest quality and rank eight denotes the lowest quality.

Table 3 provides the frequency distribution of our rankings. It is obvious that the larger average vineyard site size in the current definitions leads to a leveling out of the quality distribution compared to older definitions. While the Prussian ranking had 60 vineyards comprising 44 hectares ranked in the top quality group, the application of the Prussian ranking to current vineyard sites shows that only one, the Berncasteler Doctor, is ranked wholly in the top quality category. ${ }^{8}$ With today's list of vineyard sites only $10 \%$ of all vineyard sites belong to even the first three ranks, while most fall into ranks six and seven.

\section{B. Physical Vineyard Site Characteristics}

Data on physical vineyard attributes were taken from Stöhr et al. (1981). For each site they report the latitude, slope, altitude, orientation, depth of soil, type of soil, and size of the vineyard. The slope is given as a fraction of the vineyard that is steep, middle or flat. We constructed the variable "slope" as a weighted average of these slope measures, where $45^{0}$ is take as steep, $22.5^{0}$ is middle, and $0^{0}$ is flat. Table 3 shows the basic results of our calculations. The average slope of a Mosel vineyard is very steep, at $38^{0}$, which is not far from the optimum of $45^{\circ}$, although at least one vineyard is entirely flat.

Stöhr et al. provide the "prevailing orientation" of the vineyards in 12 categories according to the entries on a compass. These are, for example, south or south-west. We assigned a value to the variable "orientation" by the degrees of deviation of the vineyard from south: $0^{0}$ for southern orientation, $90^{\circ}$ for west or east, and $180^{\circ}$ for north. For instance, an

\footnotetext{
${ }^{8}$ The size of this vineyard is only 1.0 hectare, which is much smaller than the average vineyard size of 21.2 hectares.
} 
aspect given as south-south-west (SSW) would be measured as $30^{\circ}$, which we assume is the average orientation of the vineyard. When a vineyard had a compound orientation measure, such as "south and west" we simply assumed a 50/50 relation and defined the deviation from south as $45^{\circ}$. Overall, the data in Table 3 show that while a south-south-west orientation is the average, there is considerable variation, with at least one vineyard facing northwest $\left(135^{0}\right)$.

The altitude of a vineyard is given in meters at its lowest and its highest point. The altitude of these Mosel vineyards ranges between 320m in the Saar valley and 65m near the Rhine River. Altitude alone seems unlikely to affect a Mosel vineyard's quality given that all these vineyards are well below 500 meters (Gladstones, 1992). However, since the impact of large water bodies on diurnal air circulation is considered important for quality (Gladstones, 1992) we used data on the altitude of the Mosel River to calculate the altitude difference between the vineyard and the water body. We expect a large difference to have a negative effect on wine quality and a vineyard's ranking.

Stöhr et al. provide measures of the soil's depth as deep, moderate and flat. We calculated the depth of the soil as a single variable ranging from 0 to 1 where 1 is deep and 0 is flat. For instance a vineyard like the Erdener Praelat, which is described as deep to moderately deep, was assigned the value 0.75 . The impact of soil depth on wine quality is not well understood. On the one hand, shallow and rocky soils limit potential vine rooting depth and provide only restricted water storage capacity. On the other hand, shallow and rocky soils provide fine drainage and resistance to soil erosion, which is particularly important on slopes. Since the Mosel region is not characterized as a particularly dry climate, the latter may be the more important effect (Gladstones, 1992).

Besides the depth of the soil we also have measures of the kind of soil. This is particularly important because of the heat storage capacity of certain soils: Heat is absorbed during the day, which is followed by marked and prolonged re-radiation of warmth at night. Slate is one of the most heat absorbent soils. ${ }^{9}$ In fact, the entire Mosel-Saar-Ruwer region is characterized primarily by different forms of slate, although other soils prevail in the valley around Trier (sandstone) and between Trier and the border with Luxembourg (limestone).

\footnotetext{
${ }^{9}$ Because of its low reflectivity of solar radiation (measured by its albedo value) slate is also considered an important building material for the passive usage of solar energy. Common albedo values are: slate 0.10, wet sand 0.15 , dry sand 0.25 , concrete 0.30 , and limestone 0.40 (SolVent, 2001).
} 
However, single vineyards often contain many alternative soil types. We distinguish 12 kinds of soil: weathered slate, slate quartzite, clay slate, greywacke sandstone, quartzite, sandstone, limestone, gravel, finesoil, alluvial soil, sand, and clay/loam. We simply constructed a set of dummy variables for these soil types, where the variable takes on a 1 if this soil type exists in the vineyard and 0 otherwise.

All these variables are assumed to reflect the average characteristics of the vineyard. However, within a single vineyard conditions can deviate substantially from this average, and the deviation is likely to be larger the larger the size of the vineyard. We therefore also included in our hedonic analyses a measure of the total size of the vineyard. If the uncertainty associated with vineyard quality leads to lower quality and prices, then we expect larger vineyards to, other things the same, be of lower quality.

Though most of the vineyards of the Mosel-Saar-Ruwer region are near one of the rivers for which they are named, there are a small number of remote vineyards that are typically located near castles or cloisters. Since these vineyards do not benefit from the smaller diurnal temperature fluctuations due to proximity to a large water body, we also introduced a dummy variable that takes on the value unity when a vineyard is remote, and 0 otherwise. We expect it to have a negative effect on vineyard quality.

\section{Hedonic Model of Vineyard Quality}

Given the discrete natural order of the dependent variable and the fact that the differences between the ranks are not necessarily equivalent, we fit our hedonic model using an ordered probit function. ${ }^{10}$ In this set up the observed response is taken to depend on a latent variable $\mathrm{y}_{\mathrm{i}}{ }^{*}$, which depends linearly on the explanatory variables $\mathbf{X}_{\mathbf{i}}$ :

(1) $y_{i} *=\mathbf{X}_{\mathbf{i}} \boldsymbol{\beta}+\varepsilon_{i}$, with $\varepsilon_{i} \sim N(0,1)$

The observed category of $\mathrm{y}_{\mathrm{i}}$ is based on $\mathrm{y}_{\mathrm{i}}{ }^{*}$ and can take on eight values:

\footnotetext{
${ }^{10}$ See Greene (2003), for example.
} 
(2)

$$
y_{i}=\left\{\begin{array}{lc}
1 \text { if } & y_{i}{ }^{*} \leq \gamma_{1} \\
j \text { if } & \gamma_{j-1} \leq y_{i}{ }^{*} \prec \gamma_{j} \\
8 \text { if } & \gamma_{7} \leq y_{i}{ }^{*}
\end{array}\right\}
$$

The probability of $y_{i}$ being in a particular rank is

$$
\begin{aligned}
& \operatorname{Pr}\left(y_{i}=1\right)=\operatorname{Pr}\left(y_{i}{ }^{*}<\gamma_{1}\right)=\operatorname{Pr}\left(\mathbf{X}_{\mathrm{i}} \boldsymbol{\beta}+\varepsilon_{i}<\gamma_{1}\right) \\
& =\operatorname{Pr}\left(\varepsilon_{i}<\gamma_{1}-\mathbf{X}_{\mathbf{i}} \boldsymbol{\beta}\right)=\Phi\left(\gamma_{1}-\mathbf{X}_{\mathbf{i}} \boldsymbol{\beta}\right) \\
& \operatorname{Pr}\left(y_{i}=2\right)=\operatorname{Pr}\left(\gamma_{1} \leq y_{i} *<\gamma_{2}\right)=\operatorname{Pr}\left(\gamma_{1} \leq \mathbf{X}_{\mathbf{i}} \boldsymbol{\beta}+\varepsilon_{i}<\gamma_{2}\right) \\
& =\operatorname{Pr}\left(\varepsilon_{i}<\gamma_{2}-\mathbf{X}_{\mathrm{i}} \boldsymbol{\beta}\right)-\left(\varepsilon_{i} \leq \gamma_{1}-\mathbf{X}_{\mathbf{i}} \boldsymbol{\beta}\right) \\
& =\Phi\left(\gamma_{2}-\mathbf{X}_{\mathrm{i}} \boldsymbol{\beta}\right)-\Phi\left(\gamma_{1}-\mathbf{X}_{\mathrm{i}} \boldsymbol{\beta}\right) \\
& \operatorname{Pr}\left(y_{i}=8\right)=\operatorname{Pr}\left(y_{i} * \geq \gamma_{7}\right)=\operatorname{Pr}\left(\mathbf{X}_{\mathbf{i}} \boldsymbol{\beta}+\varepsilon_{i} \geq \gamma_{7}\right) \\
& =\operatorname{Pr}\left(\varepsilon_{i} \geq \gamma_{7}-\mathbf{X}_{\mathbf{i}} \boldsymbol{\beta}\right)=\Phi\left(\mathbf{X}_{\mathbf{i}} \boldsymbol{\beta}-\gamma_{7}\right)
\end{aligned}
$$

where $\Phi($.$) denotes the cumulative normal distribution function.$

The results of the estimation are contained in Table 5 for several specifications of the basic set of independent variables $(\mathbf{X})$ that determine quality. These vineyard quality variables, discussed earlier, are listed as the row labels in Table 5. In a first specification (column 1) we include variables related to soil characteristics and include as separate variables the three determinants (slope, orientation, and latitude) of our measure of the solar energy captured by the vineyard. This is a reduced form regression that we use to test the basic predictions of our model of energy retention. In order to extrapolate the impact of a change in climate on vineyard quality it is essential that this model of energy retention provides a reasonable approximation of how heat affects vineyard site quality.

The results in columns 2-3 reflect the imposition of the constraint that the three energy variables are captured by the specific formula contained in the Appendix. Comparing the unconstrained results in column 1 to the results in columns 2-3 provides a basic empirical test of the accuracy of this formula for predicting how solar energy affects vineyard prices. 
In fitting the constrained model we aggregated the variables slope, orientation, and latitude in two different ways to determine a measure of potential energy. In column 2 we use a formula that assumes that the energy the plant receives throughout the entire year is the appropriate measure, while in column 3 we assume that the energy the plant receives in the fall is the appropriate measure. Neither of these measures is likely to be ideal, but they are very highly correlated in any event. Moreover, these two extreme cases span all the reasonable alternatives.

A comparison of the results indicates that the constrained measure of "fall energy" in column 3 provides a slightly better fit to the data (judging from the maximized likelihood ratio) than the measure of "annual energy," and so we rely on it for further analyses. A straightforward way to assess the goodness-to-fit qualities of an ordered probit model is a comparison of predicted and actual results. In Table 6 we use the results of column 3 of Table 5 to assess the model's predictive quality. Predicted quality ranks are listed in the first column, while the distribution of the deviations of the actual from the predicted ranks is listed in the remaining columns for each predicted rank. For example, 85 vineyards are predicted to be in the largest category, rank 6, of which 54 predictions are correct, 28 are off by one rank, and 3 are off by two ranks. Overall, the ranks of $50.9 \%$ of all vineyards are predicted correctly, while $42.2 \%$ of the predictions are off by a deviation of one rank. Taken together, the average deviation is only 0.57 quality ranks.

A test of the constraint that "energy" determines vineyard quality in the precise form we have assumed may be based on a comparison of twice the difference in the log likelihood between columns 1 and 3 of Table 5. This test rejects the precise constraint at any reasonable level of statistical significance, but it is apparent from Table 6 that the constrained measure captures the major variability in the data. As a result, we use the basic results in column 3 of Table 5 in simulating the effects of climate change in the analysis below.

Since the vineyard ranking is defined as 1 being best and 8 being worst, a positive influence of an independent variable on the quality of the vineyard is indicated by a negative sign. It is apparent that the potential solar radiation variable has a very significant effect on the rating of a vineyard site. In addition, slate of any type increases the quality of the vineyard, especially weathered slate and clay slate. As expected, sand, gravel, and loam have 
a far lower ability to store heat, and are, by comparison with slate, less advantageous for the vineyard's quality.

The results in Table 5 also provide evidence for the importance of a water body close to the vineyard. Vineyards that are remote from the Mosel River, and those that are far above the river, suffer from these features. Both of these factors lead to larger diurnal temperature fluctuations and thus to lower quality vineyard sites.

Finally, the estimates confirm the hypothesis that larger sized vineyards, given our measurements of the other measures of a vineyard's qualities, do suffer a disadvantage in quality.

The estimated coefficients of an ordered probit model must be interpreted with some care. The sign of $\hat{\boldsymbol{\beta}}$ shows the direction of the change in the probability of falling in the endpoint rankings $\left(\mathrm{y}_{\mathrm{i}}=1\right)$ and $\left(\mathrm{y}_{\mathrm{i}}=8\right)$ when $\mathbf{X}$ changes. $\operatorname{Pr}\left(\mathrm{y}_{\mathrm{i}}=1\right)$ changes in the opposite direction of the sign of $\hat{\boldsymbol{\beta}}$ and $\operatorname{Pr}\left(\mathrm{y}_{\mathrm{i}}=8\right)$ changes in the same direction as the sign of $\hat{\boldsymbol{\beta}}$. The effects on the probability of falling in any of the middle rankings are unclear, a priori.

Table 7 reports the marginal effects of the significant variables of the model listed in column 3 of Table 5 that uses the fall radiation variable. Marginal effects are measured relative to the baseline probabilities given in the first line. As the Table shows, the percentage of vineyard sites expected to be ranked number one is $0.27 \%$, while the percentage for rank two is $3.32 \%$. The following set of rows report the effect of a change of ten percent in the value of an independent variable on these percentages. Thus, an increase in potential solar radiation by $10 \%$ will increase the vineyard's probability of being ranked number one by $1.19 \%$ to $1.46 \%$. Similarly, the probability of being ranked number two will increase from $3.34 \%$ to $9.33 \%$. Since the changes sum up to zero, energy increases entail a drop in the likelihood of being in rank number six, seven, or eight. Similarly, deeper soil, a greater altitude difference between the vineyard and the Mosel River, and a larger vineyard size decrease the probabilities of being in high quality ranks. However, it is apparent that the marginal effect of the solar radiation variable is very substantial compared to the effects of each of these other variables. 
The marginal effects of the dummy variables were calculated as the effect of the difference between the values zero and one while holding the other variables at their mean values. The marginal effects of these variables show the great importance of soil type on vineyard quality and also the great importance of having a vineyard site that is influenced by proximity to the Mosel River.

\section{Solar radiation and global warming}

Since vineyard quality is dependent on solar energy absorption, it follows that, in a place like the Mosel Valley, climate change that leads to warmer temperatures will lead to higher quality wines and prices. Land prices, which represent the capitalized value of these wine prices, less other costs of production, should therefore also increase. It follows that the many recent studies that predict that climate change is leading to warmer temperatures also predict increased land values in areas like the Mosel Valley. In what follows we set out a simple model that permits us to estimate what the effect of climate change would be on the overall quality of the Mosel's vineyards and thus on their prices.

Most scenarios about global temperature change ${ }^{11}$ provide a summary measure of expected temperature changes, whereas we have established the connection between solar energy reception and vineyard quality. Although there is, of course, a relationship between solar energy and the Earth's temperature, the relationship involves a comparison of energy inflow and outflow. Absorbed energy from the sun is converted to heat, which causes the Earth to warm up. However, the temperature maximum does not occur at the time of maximum solar energy input, but later. This lag is the result of the energy storage system and the resistance to energy flows. Figure 4 shows that, in a simple model, temperature is the result of the influx of solar energy and the energy radiated by the Earth. Thus, as long as the net influx is positive temperatures will rise and vice versa. The result is that the temperature maximum is attained after the influx maximum.

We use the following simplified model to establish the interrelations between solar radiation and temperature (see Hartmann (1994) and Andrews (2000)) for the purpose of simulating the effect of various global warming scenarios on vineyard quality and prices.

\footnotetext{
${ }^{11}$ See Johns, et. al. (1997).
} 
With radius $\mathrm{R}$ and the Earth's receptive surface $\pi R^{2}$, the energy absorbed by the planet is equal to

(4) $(1-\alpha) \pi R^{2} S=$ (energy absorbed by the Earth)

where $\alpha$ is the albedo number of the Earth's atmosphere and S is the solar constant. We assume that $\alpha=.3$, which implies that the Earth reflects $30 \%$ of the incoming solar energy back to space.

If the Earth is assumed to emit like a blackbody ${ }^{12}$ the energy radiated from the planet is, according to the Stefan-Boltzmann law, equal to

$$
\left(4 \pi R^{2}\right) \sigma T_{s}^{4}=(\text { energy radiated from the Earth })
$$

where $T_{\mathrm{s}}$ is the planet's surface temperature and $\sigma$ is the Stefan-Boltzmann constant. ${ }^{13}$

Setting (6) and (7) equal and solving for the equilibrium temperature yields

(6) $T_{S}=\sqrt[4]{(1-\alpha) S / 4 \sigma}$

According to equation (8) the Earth's surface temperature is equal to $255 \mathrm{~K}$ (or $-18^{\circ} \mathrm{C}$ ) which is well below the measured average temperature of approximately $288 \mathrm{~K}$ (or $15^{\circ} \mathrm{C}$ ).

To make this model more realistic it is necessary to incorporate the atmospheric effects that are associated with the Earth and which act like a greenhouse. If we assume an atmosphere that absorbs all long-wave terrestrial radiation but is transparent to short-wave solar radiation, at the top of this atmospheric layer the energy balance remains the same with

(7) $\sigma T_{a}^{4}=(1-\alpha) S / 4$

\footnotetext{
${ }^{12}$ A blackbody absorbs all the radiant energy it receives, regardless of the wavelength.

${ }^{13}$ The Stefan-Boltzmann constant is equal to $5.67 * 10^{-8} \mathrm{JK}^{-1}$.
} 
where $\mathrm{T}_{\mathrm{a}}$ is the atmospheric temperature. Assuming further that $\sigma T_{s}^{4}=2 \sigma T_{a}^{4}$, that is, half of the energy absorbed by the atmosphere is reflected back to the Earth, we get

(8) $T_{S}=\sqrt[4]{(1-\alpha) S / 2 \sigma}$

Equation (8) predicts an average temperature of $303 \mathrm{~K}$ ( or $30^{\circ} \mathrm{C}$ ) for the Earth, which is much closer to the observed value.

Equation (8) allows us to compute changes in radiant energy associated with any given temperature variation. Accordingly, a temperature increase of $1{ }^{\circ} \mathrm{C}$ is associated with additional radiation energy of $47.43 \mathrm{MJ} /$ month. Similarly, a temperature increase of $2^{\circ} \mathrm{C}$ or $3^{\circ} \mathrm{C}$ translates into radiation energy increases of 94.87 and $142.82 \mathrm{MJ} / \mathrm{month}$, respectively.

Table 8 reports the changes in a vineyard's probability of being in a certain rank using the results in Table 7 and various assumptions about the likely magnitude of climate change. For example, a temperature increase of $1^{\circ} \mathrm{C}$ corresponds to an increase in potential solar radiation of $47.43 \mathrm{MJ} / \mathrm{month}$, which changes the likelihood of an average vineyard being rated number one by $0.32 \%$, that is, from $0.25 \%$ to $0.57 \%$. Similarly, the likelihood of being rated number eight will decrease by $2.13 \%$, that is, from $9.74 \%$ to $7.61 \%$. Predicted temperature increases in the Mosel area for the near term are around $2^{\circ} \mathrm{C}$. for moderate warming scenarios, with higher predicted temperature increases in the longer term. These three scenarios should provide a general indication of magnitudes to be expected. ${ }^{14}$

As also reported in Table 8, the number of vineyards in each category will change with increased warming. While in the base scenario only 10 vineyards were rated quality one, two, or three, a temperature increase of $1^{\circ} \mathrm{C}$ will lift this number to 18 . In comparison, if temperatures increased by $3^{\circ} \mathrm{C}, 68$ vineyards would be rated within the best three categories.

In order to convert these changes in vineyard quality ranking into changes in vineyard prices we weight land values in each quality category by the size of the respective

\footnotetext{
${ }^{14}$ See, for example, the Hadley Center's work in Johns, et al. (1997).
} 
vineyards. While the size of each vineyard is given in Stöhr et al. (1981), the land value of each quality class was taken from land sales surveys provided by the governments of the four counties that cover the Mosel area (Landkreis Bernkastel-Wittlich, 2004; Landkreis CochemZell, 2004; Landkreis Mayen-Koblenz, 2004; Landkreis Trier, 2004). The surveys provide average sales prices of vineyard land in 2003, differentiated by municipality and vineyard quality level. This permits us to estimate vineyard specific market prices ${ }^{15}$. From these data we calculated average land values for each quality category. The land values range from $€$ 0.50 per $\mathrm{m}^{2}$ for vineyards in quality category 8 to $€ 130$ per $\mathrm{m}^{2}$ for vineyards in quality category $1^{16}$.

Table 9 reports the hectares of vineyards in each quality category and in each scenario. While in the baseline scenario only 30 hectares of vineyards are within the top three quality ranks, a temperature increase of $1{ }^{\circ} \mathrm{C}$ would put more than 100 hectares in these categories. These temperature increases also lead to higher predicted land values. In fact, because of the steeply increasing land prices as we move from lower to higher quality vineyards, the change in land values is proportionally greater than the increase than the mere increase in temperatures. While a $1{ }^{\circ} \mathrm{C}$ increase results in an increase in the total vineyard land value of $20 \%$ (from $€ 231$ million to $€ 276$ million), a $3{ }^{\circ} \mathrm{C}$ increase in temperature will double the overall land value.

\section{Conclusion}

The basic results in this paper show how the link between temperature and solar radiation can be used to construct a structural model to predict changes in agricultural land prices and crop values associated with climate change. The key to building this relationship is to establish the hedonic relation between the determinants of solar radiation received by an area and land values. For vineyard areas many of the key hedonic characteristics of the vineyard are related to energy absorption, which leads to an important effect of climate

\footnotetext{
${ }^{15}$ The reported sales prices reflect only the land value and do not include the value of vines that might be planted on it.

${ }^{16}$ Our calculations are based on the following land values per m2: $€ 130$ (rank 1), $€ 20$ (rank 2), $€ 10$ (rank 3), $€$ 7 (rank 4), $€ 4$ (rank 5), $€ 2$ (rank 6), $€ 1$ (rank 7), and $€ 0.50$ (rank 8). It is apparent from these calculations that the prices drop dramatically with quality.
} 
change on crop quality. Grape vines have very low radiation use efficiency (RUE), and no doubt the hedonic relationship we estimate is related to this fact. It seems that further research might be usefully guided by measuring the hedonic relationship of solar energy received for crops with different RUE's.

Although our purpose here has been to use this hedonic relationship to evaluate the effect of climate change on land values, it should be clear that, to the extent other undeveloped vineyard areas may exist in the world, this relationship could be used to evaluate the economic viability of new planting. In short, this hedonic relationship could be used for determining vineyard site selection in undeveloped areas.

Our empirical results indicate that climate change may result in considerable increases in the value of the Mosel Vineyard region because of increasing wine quality. A moderate $1{ }^{\circ} \mathrm{C}$ temperature increase would lead to an aggregate increase in land value of 20 percent, while an increase of $3^{\circ} \mathrm{C}$ would more than double the land value.

There are several limitations of these results. First, our empirical analysis does not take account of general equilibrium effects that might result in a restructuring of land prices. The Mosel Valley is suited primarily for grape growing only, so a chance in the relative price of vineyards of different quality induced by climate change could have a dramatic effect on our calculations. Second, our results provide only a small part of an overall appraisal of the role of climate change on agricultural values.

\section{References}

Andrews, D.G. (2000), An introduction to atmospheric physics. Cambridge University Press, Cambridge, UK.

Beck, O. (1869), Der Weinbau an der Mosel und Saar. Nebst einer vom königlichen Katasterinspekteur Steuerrath Clotten zu Trier angefertigten Weinbaukarte. Selbstverlag der königlichen Regierung zu Trier. Trier.

Bernkasteler Ring (1999), 100 Jahre Bernkasteler Ring 1899 - 1999. Krämer-Druck, Bernkastel-Kues.

Castelan-Estrada, M. (2001), Répartition de la biomasse chez Vitis vinifiera ; rendement de conversion du rayonnement solaire global et coûts energétiques. Doctoral dissertation at 
Institut National Agronomique Paris-Grignon. INRA Bordeaux.

online: http://www.bordeaux.inra.fr/ECAV/doc/castelan.pdf

Clotten (1868), Saar und Mosel Weinbaukarte für den Regierungsbezirk Trier. Lintz Verlag, Trier.

Davidson, R. and MacKinnon, J. (1993), Estimation and inference in econometrics. Oxford University Press, Oxford.

Deschenes, O and M. Greenstone (2006), The Economic Impacts of Climate Change:

Evidence from Agricultural Profits and Random Fluctuations in Weather, MIT Department of Economics Research Paper No. 04-25.

Diemer, E. (1937), Deutschlands Weinbauorte und Weinbergslagen. $4^{\text {th }}$ edition, Verlag der Deutschen Wein-Zeitung, Mainz.

Duffie J.A., Beckman, W. A. (1991), Solar Engineering of Thermal Processes. $2^{\text {nd }}$ edition, John Wiley \& Sons Inc, New York.

Environmental Protection Agency (2002), The soil and water assessment tool SWAT 2000, Appendix A. Texas Water Resources Institute, Temple/TX.

Farquharson, J.E. (1986), The Agrarian Policy of National Socialist Germany. In: Moeller, E. (ed.), Peasants and Lords in Modern Germany: Recent Studies in Agricultural History. Allen \& Unwin, Boston.

Flotow, G. Von (1820), Versuch einer Anleitung zu Abschätzung der Grundstücke nach Classen, besonders zu Behufe einer Grundsteuer-Rectification. Hartmann, Leipzig.

Gebhard, G. (1824), Grundsteuer-Kataster aus der Messung und dem Reinertrage der einzelnen Grundstücke entwickelt. Finsterlin, München.

Gladstones, J. (1992), Viticulture and Environment. Winetitles, Adelaide.

Goldschmidt, F. (1925), Deutschlands Weinbauorte und Weinbergslagen. $3^{\text {rd }}$ edition. Verlag der Deutschen Wein-Zeitung, Mainz.

Greene, W. (2003), Econometric analysis. $5^{\text {th }}$ edition. Prentice Hall, Upper Saddle River, New Jersey.

Hartmann, D.L. (1994), Global physical climatology. Academic Press: San Diego and New York.

Hay, R. K. and Walker, A.J. (1989), An Introduction to the Physiology of Crop Yield. Longman Scientific, Essex.

Heger, J.P. (1905), Die Klassifikation der Moselweine in alter und neuer Zeit. In: Trierische Chronik. Vol. 1, no. 6, pp.81-89. 
Iqbal, M. (1983), An Introduction to Solar Radiation. Academic Press, Toronto.

Johns, T.C., R.E. Carnell, J.F. Gregory, J. Mitchell, C. Senior, S. Test, and R.A. Wood (1997), "The Second Hadley Centre Coupled Ocean-Atmosphere GCM: Model Description, Spinup and Validation," Climate Dynamics, Vol. 13, 103-134.

Klein, S.A. (1977), Calculation of Monthly Average Insolation on Tilted Surfaces. In: Solar Energy, Vol. 19, pp. 325-329, Vol. 20, p. 441 (erratum), and Vol. 25, p. 287 (comment).

Koch, Fr. W. (1881), Der Weinbau an der Mosel und Saar. Verlag der Fr. Lintz'schen Buchhandlungen/Trier.

Koch, H.-J. (1998), Der Weinlagename als Herkunftsangabe und Qualitätshinweis. Rechtsgeschichte, aktuelle Regelungen, Reformvorschläge (Schriften zur Weingeschichte. Nr. 123), Gesellschaft für Geschichte des Weines e.V., Wiesbaden.

Landkreis Bernkastel-Wittlich (2004), Bericht über den Grundstücksmarkt im Landkreis Bernkastel-Wittlich. Bernkastel 2004.

Landkreis Cochem-Zell (2004), Bericht über den Grundstücksmarkt im Landkreis CochemZell, Cochem.

Landkreis Mayen-Koblenz (2004), Bericht über den Grundstücksmarkt im Landkreis MayenKoblenz, Vermessungs- und Katasteramt, Koblenz .

Landkreis Trier (2004), Bericht über den Grundstücksmarkt im Landkreis Trier, Vermessungs- und Katasteramt, Trier.

Lindauer, J. (1815), Beweis, dass die in acht Procenten des Rohertrages ausgesprochene Grundsteuer gerecht und national-ökonomisch sey. Und: dass der Rohertrag der Grundstücke zur Grundlage ihrer Werthes-Schätzung angenommen werden könne. München.

Le Ministre des Finances de la France (1811), Receuil méthodique des lois, décrets, réglemens, instructions et decisions sur le cadastre de la France. Paris.

Lintz, F. (ed.) (1897), Mosel Weinbaukarte für den Regierungsbezirk Coblenz. Lintz Verlag, Trier.

Lintz, J. (1925), Saar und Mosel Weinbaukarte für den Regierungsbezirk Trier. $5^{\text {th }}$ edition. Lintz Verlag, Trier.

Markham, D. (1998), 1855: a history of the Bordeaux classification. McGraw-Hill, New York.

Mendelsohn, R., Nordhaus, W.D., and D. Shaw (1994), "The Impact of Global Warming on Agriculture: A Ricardian Analysis,” American Economic Review, Vol. 84, 753-771. 
Meyer, F. (1926), Weinbau und Weinhandel an Mosel, Saar und Ruwer. Görres-Druckerei, Koblenz.

Milthorp, F.L. and Moorby, J. (1979), An Introduction to Crop Physiology. $2^{\text {nd }}$ edition, Cambridge University Press, Cambridge.

Monteith, J.L. (1977), Climate and the efficiency of crop production in Britain. In:

Philosophical Transactions of the Royal Society of London Series B - Biological Sciences, Vol. 281, pp. 277-294.

Müller, M. (1980), Säkularisation und Grundbesitz. Zur Sozialgeschichte des Saar-MoselRaumes 1794-1813. Harald Boldt Verlag, Boppard.

Penning-Roswell, E. (1986), Wines of Bordeaux, $6^{\text {th }}$ edition, Penguin Bookds, London.

Pigott, S. (1995), The Wine Atlas of Germany and Traveler's Guide to the Vineyards. Mitchell Beazley Ltd., London.

Salisbury, F. and Ross, C.W. (1992), Plant Physiology. $4^{\text {th }}$ edition, Wadsworth Publishing Company, Belmont/CA.

Schieder, W. (1991), Säkularisation und Mediatisierung in den vier rheinischen Departements 1803-1813. Vol. 1-4, Harald Boldt Verlag, Boppard.

Schimmelfennig, F.G. (1831), Historische Darstellung der Grundsteuer-Verfassungen in den Preußischen Staaten. Logier, Berlin.

Schlenker, W., Hanemann, W.M., and A. Fisher (2005), "Will U.S. Agriculture Really Benefit from Global Warming?: Accounting for Irrigation in the Hedonic Approach," American Economic Review, Vol. 95, 395-406.

Schlenker, W., Hanemann, W.M., and A. Fisher (2006), "The Impact of Global Warming on U.S. Agriculture: An Econometric Analysis of Optimal Growing Conditions," Review of Economics and Statistics, Vol. 88, 113-125.

Sinclair, T.R. and Muchow, R.C. (1999), Radiation use efficiency. In: Advances in Agronomy, Vol. 65, pp. 215-265.

Smart, R.E. (1973), Sunlight interception by vineyards. In: American Journal of Enology and Viticulture, Vol. 24, pp. 141-147.

Smart, R. E. (1976), Implications of the radiation microclimate for productivity of vineyards. Doctoral thesis, Cornell.

SolVent (2001), http://www.brunel.ac.uk/research/solvent/pdf/climate.pdf 
Statistisches Bundesamt (1998), Fachserie 3, Land- und Fortstwirtschaft, Fischerei, Reihe 3.1.5 Landwirtschaftliche Bodennutzung. Wiesbaden.

Stöhr, W., Cüppers, H., Fass, K.-H. (1981), Mosel-Saar-Ruwer. (Ambrosi, H. And Breuer B. (ed.), Vinothek der deutschen Weinberg-Lagen.). Seewald. Stuttgart.

Tornow, W. (1972), Chronik der Agrarpolitik und Agrarwirtschaft des Deutschen Reiches von 1933-1945. Berichte über Landwirtschaft, N.F., Sonderheft 188, Paul Parey, Hamburg.

Winter-Tarvainen, A. (1992), Weinbaukrise und preußischer Staat. Preußische Zoll- und Steuerpolitik in ihren Auswirkungen auf die soziale Situation der Moselwinzer im 19. Jahrhundert. (Trierer Historische Schriften, Band 18). Verlag Trierer Historische Forschungen. Trier. 


\section{Appendix}

From Duffie and Beckman (1991) as well as Iqbal (1983) we calculate the daily extraterrestrial solar radiation $H_{O \beta \gamma}$ as

$$
\begin{aligned}
H_{O \beta \gamma}=( & 12 / \pi) I_{S C} E_{O}\left(\cos \beta \sin \delta \sin \phi\left|\omega_{s s}-\omega_{s r}\right| \pi / 180\right. \\
& -\sin \delta \cos \phi \sin \beta \cos \gamma\left|\omega_{s s}-\omega_{s r}\right| \\
& +\cos \phi \cos \delta \cos \beta\left|\sin \omega_{s s}-\sin \omega_{s r}\right| \\
& +\cos \delta \cos \gamma \sin \phi \sin \beta\left|\sin \omega_{s s}-\omega_{s r}\right| \\
& \left.+\cos \delta \sin \beta \sin \gamma\left|\cos \omega_{s s}-\cos \omega_{s r}\right|\right)
\end{aligned}
$$

with

$$
\begin{aligned}
& \omega_{s r}=\min \left[w_{s}, \cos ^{-1}\left(\frac{-x y-\sqrt{x^{2}-y^{2}+1}}{x^{2}+1}\right)\right] \\
& \omega_{s s}=-\min \left[w_{s}, \cos ^{-1}\left(\frac{-x y+\sqrt{x^{2}-y^{2}+1}}{x^{2}+1}\right)\right]
\end{aligned}
$$

for $\gamma>0$, i.e., the surface is oriented toward the east and

$$
\begin{aligned}
& \omega_{s r}=\min \left[w_{s}, \cos ^{-1}\left(\frac{-x y+\sqrt{x^{2}-y^{2}+1}}{x^{2}+1}\right)\right] \\
& \omega_{s s}=-\min \left[w_{s}, \cos ^{-1}\left(\frac{-x y-\sqrt{x^{2}-y^{2}+1}}{x^{2}+1}\right)\right]
\end{aligned}
$$

for $\gamma<0$, i.e., the surface is oriented toward the west, where

$$
\begin{aligned}
& x=\frac{\cos \phi}{\sin \gamma \tan \beta}+\frac{\sin \phi}{\tan \gamma} \\
& y=\tan \delta\left(\frac{\sin \phi}{\sin \gamma \tan \beta}-\frac{\cos \phi}{\tan \gamma}\right)
\end{aligned}
$$


$\omega_{s}=\cos ^{-1}(-\tan \phi \tan \delta)$.

With

$I_{S C} \quad$ Solar Constant $\left(4.921 \mathrm{MJ} / \mathrm{m}^{2} \mathrm{hr}\right)$

$\mathrm{E}_{\mathrm{o}} \quad$ Eccentricity Correction Factor (tables for each day of the year)

$\beta \quad$ Slope, the angle between the plane of the surface and the horizontal, $0^{\circ} \leq \beta \leq 180^{\circ}$, ( $\beta>90^{\circ}$ implies that the surface is downward facing).

$\delta \quad$ Declination, the angular position of the sun at solar noon (i.e., when the sun is on the local meridian) with respect to the plane of the equator, north positive, $-23.34^{\circ} \leq \delta \leq 23.45^{\circ}$ (tables for each day of the year)

$\phi \quad$ Latitude, the angular location north or south of the equator, north positive $-90^{\circ} \leq \phi \leq 90^{\circ}$

$\gamma \quad$ Surface azimuth angle, the deviation of the projection on an horizontal plane of the normal to the surface from the local meridian, with zero due south, east positive, and west negative; $-180^{\circ} \leq \gamma \leq 180^{\circ}$

$\omega_{s s} \quad$ Sunset hour angle for a tilted surface

$\omega_{s r} \quad$ Sunrise hour angle for a tilted surface

$\omega_{s} \quad$ Sunrise hour angle for a horizontal surface.

The daily extraterrestrial solar radiation was multiplied by the number of days of the respective month in order to obtain the monthly value. Data for the characteristic average day for each month are contained in Klein (1977), and values for the eccentricity correction factor, $\mathrm{E}_{\mathrm{o}}$, and the declination, $\delta$, respectively, are given in Appendix Table 1. 


\section{Appendix Table 1}

Characteristic Eccentricity Correction Factor and Declination

\begin{tabular}{lcccr}
\hline \multicolumn{1}{c}{ month } & $\begin{array}{c}\text { day of the } \\
\text { month }\end{array}$ & $\begin{array}{c}\text { Day of the } \\
\text { year }\end{array}$ & $\mathrm{E}_{\mathrm{o}}$ & $\delta$ \\
\hline January & 17 & 17 & 1.0340 & -20.88 \\
February & 16 & 47 & 1.0251 & -12.53 \\
March & 16 & 75 & 1.0108 & -1.93 \\
April & 15 & 105 & 0.9932 & 9.60 \\
May & 15 & 135 & 0.9780 & 18.77 \\
June & 11 & 162 & 0.9692 & 23.09 \\
July & 17 & 198 & 0.9673 & 21.34 \\
August & 16 & 228 & 0.9746 & 13.94 \\
September & 15 & 258 & 0.9885 & 3.27 \\
October & 15 & 288 & 1.0058 & -8.30 \\
November & 14 & 318 & 1.0222 & -18.11 \\
December & 10 & 344 & 1.0319 & -22.28 \\
\hline
\end{tabular}

According to Klein (1977) and Duffie and Beckman (1991). 
Table 1

Solar Radiation Efficiency of Selected Crops

\begin{tabular}{|c|c|c|}
\hline & crop & $\mathrm{RUE}_{\max }{ }^{\mathrm{a})}$ \\
\hline \multirow[t]{3}{*}{$\mathrm{C}_{4}$ species } & Sugarcane & 2.0 \\
\hline & Maize & 1.8 \\
\hline & Grain Sorghum & 1.7 \\
\hline \multirow[t]{5}{*}{$\mathrm{C}_{3}$ species } & Potato & 1.7 \\
\hline & Wheat & 1.6 \\
\hline & Sunflower & 1.6 \\
\hline & Rice & 1.4 \\
\hline & Soybean & 1.3 \\
\hline \multirow[t]{4}{*}{ Other } & Tomato & $1.5^{\mathrm{b})}$ \\
\hline & Cauliflower & $1.1^{\mathrm{b})}$ \\
\hline & Apple & $0.8^{\mathrm{b})}$ \\
\hline & Grapevine (Merlot) & $0.7^{\mathrm{c})}$ \\
\hline \multicolumn{3}{|c|}{$\begin{array}{l}\text { According to Sinclair and Muchow (1999), }{ }^{\text {a) }} \text { maximum RUE in gram dry matter } \mathrm{MJ}^{-1} \mathrm{~m}^{-2} \text { of } \\
\text { intercepted solar radiation; }{ }^{\text {b) }} \text { Environmental Protection Agency (2002); }{ }^{\text {c) }} \text { Castelan-Estrada } \\
\text { (2001). }\end{array}$} \\
\hline
\end{tabular}


Table 2

\section{French ranking of Mosel vineyards in 1804}

10 grades by village and repurchase price

\begin{tabular}{|c|c|c|}
\hline Grade & Name of the village & $\begin{array}{l}\text { Repurchase price } \\
\text { in Francs/1000 liter }\end{array}$ \\
\hline 1 & Dusemond (Brauneberg) & 172 \\
\hline 2 & Piesport, Wehlen, Machern, Graach, Zeltingen, Erden, Lösenich & 150 \\
\hline 3 & $\begin{array}{l}\text { Niederremmel, Müstert, Reinsport, Berncastel, Grünhaus, Kesten, } \\
\text { Oberremmel, Minheim }\end{array}$ & 140 \\
\hline 4 & $\begin{array}{l}\text { Kous (Cues), Lieser, Winterich, Ürzig, Kröf, Köwerich, Mülheim, Thron, } \\
\text { Kinheim, Kindel, Wolf, Kasel, St. Matthias, Okfen, Kastel, Staadt, Neumagen }\end{array}$ & 129 \\
\hline 5 & Trittenheim, Mehring, Monzel, Waltrach, Isselbach, Konz & 118 \\
\hline 6 & $\begin{array}{l}\text { Rachtig, Awelsbach, Mertesdorf, Veldenz, Thörnich, Reul, Maring, Burgen, } \\
\text { Olewig, Krutweiler, Ayl, Bibelhausen, Irsch/Saar }\end{array}$ & 107 \\
\hline 7 & $\begin{array}{l}\text { Pfalzel, Pichter, Merzlich, Niederleuken, Klüsserath, Wawern, Pölich, } \\
\text { Köwerich, Platten, Filzen/Mosel, Neudorf, Trier, Hamm, Komlingen, Nennig, } \\
\text { Mies, Helfand, Detzem, Schweich, Longen, Lörsch, Ensch, Longuich, Osan }\end{array}$ & 96 \\
\hline 8 & $\begin{array}{l}\text { Niedermennig, Leiwen, Schleich, Fell, Löwenbrück, Kreutz, Kürenz, Feyen, } \\
\text { Palzem, Rölingen, Fasterau, Beurig, Perl, Sendorf }\end{array}$ & 86 \\
\hline 9 & $\begin{array}{l}\text { Wittlich, Andel, Pallien, Erang, Metzdorf, Euren, Zewen, Oberkirch, Monaise, } \\
\text { Niederkirch, Ruwer, Pellingen, Irsch-Olewig, Kenn, Feilz, Plein, Luxem, } \\
\text { Kernscheid, Issel, Bekond, Hetzrath, Rivenich, Riol }\end{array}$ & 75 \\
\hline 10 & $\begin{array}{l}\text { Bengel, Springirsbach, Korlingen, Drees, Bergweiler, Hupperat, Flusbach, } \\
\text { Bausendorf, Olkenbach }\end{array}$ & 64 \\
\hline
\end{tabular}


Table 3

Distribution of Vineyard Site Ranking

\begin{tabular}{ccc}
\hline Rank & Number & Percent \\
\hline 1 & 1 & 0.29 \\
2 & 11 & 3.20 \\
3 & 23 & 6.69 \\
4 & 59 & 17.15 \\
5 & 63 & 18.31 \\
6 & 85 & 24.71 \\
7 & 69 & 20.06 \\
8 & 33 & 9.59 \\
\hline total & 344 & 100.00 \\
\hline
\end{tabular}

Own calculations. 
Table 4

Descriptive Statistics of Variables

\begin{tabular}{|c|c|c|c|c|}
\hline Variable & Mean & Std. Deviation & Minimum & Maximum \\
\hline Rank & 5.52 & 1.56 & 1 & 8 \\
\hline Slope (degree) & 38.28 & 7.97 & 0 & 45 \\
\hline Orientation $^{1}$ & 46.71 & 28.68 & 0 & 135 \\
\hline Latitude degree) & 49.95 & 0.20 & 49.61 & 50.34 \\
\hline Altitude (in meters) & 120.02 & 43.83 & 22 & 226 \\
\hline Hectare & 26.31 & 37.99 & 0.2 & 420 \\
\hline Energy $\left(\mathrm{GJm}^{-2}\right.$ per year) & 11.27 & 1.47 & 5.57 & 12.8 \\
\hline Energy ( $\mathrm{MJm}^{-2}$ in Sept/Oct) & 1872.3 & 318.0 & 694.6 & 2237.4 \\
\hline
\end{tabular}




\section{Table 5}

\section{Determinants of the Vineyard Site Ranking Results of the Ordered Probit Model}

\begin{tabular}{|c|c|c|c|}
\hline Variable & (1) & $\begin{array}{c}(2) \\
\text { (Annual Energy) }\end{array}$ & $\begin{array}{c}(3) \\
\text { (Fall Energy) }\end{array}$ \\
\hline Slope & $-3.13 * * *(-6.44)$ & & \\
\hline Orientation & $0.04 * * *(12.71)$ & & \\
\hline Latitude & $0.29(0.57)$ & & \\
\hline Energy $\left(\mathrm{KJm}^{-2}\right)$ & & $-0.86^{* * *}(-11.50)$ & $-4.10^{* * *}(-11.53)$ \\
\hline Clay Slate & $-2.35 * * *(-7.21)$ & $-2.09 * * *(-6.79)$ & $-2.13 * * *(-6.89)$ \\
\hline Weathered Slate & $-1.59 * * *(-5.92)$ & $-1.32 * * *(-5.10)$ & $-1.35^{* * *}(-5.20)$ \\
\hline Slate Quartzite & $-0.72 *(-2.23)$ & $-0.53^{+}(-1.71)$ & $-0.57^{+}(-1.86)$ \\
\hline Sandstone & $-0.38(-0.97)$ & $-0.17(0.32)$ & $-0.20(-0.41)$ \\
\hline Finesoil & $-0.11(-0.41)$ & $-0.27(-1.19)$ & $-0.26(-1.15)$ \\
\hline Sand & $1.05 * * *(3.48)$ & $1.12 * * *(4.38)$ & $1.08 * * *(4.21)$ \\
\hline Clay, Loam & $0.86^{* * *}(3.88)$ & $0.91 * * *(4.10)$ & $0.89 * * *(4.04)$ \\
\hline Quartzite & $0.65^{+}(1.70)$ & $0.81 *(2.15)$ & $0.80 *(2.14)$ \\
\hline Gravel & $-0.04(-0.08)$ & $0.17(0.37)$ & $0.12(0.25)$ \\
\hline Graywacke & $-0.03(-0.12)$ & $0.13(0.88)$ & $0.10(0.68)$ \\
\hline Limestone & $-0.20(-0.31)$ & $0.17(0.25)$ & $0.06(0.09)$ \\
\hline Alluvial Soil & $-0.08(-0.20)$ & $0.02(0.07)$ & $-0.04(-0.13)$ \\
\hline Depth of Soil & $1.70 * * *(6.06)$ & $1.94 * * *(6.97)$ & $1.91 * * *(6.87)$ \\
\hline $\begin{array}{l}\text { Altitude } \\
\text { Difference }^{1}\end{array}$ & $0.01 * * *(3.57)$ & $0.01 * * *(2.83)$ & $0.01 * * *(2.88)$ \\
\hline Vineyard Size & $0.01 * * *(5.39)$ & $0.01 * * *(6.71)$ & $0.01 * * *(6.61)$ \\
\hline Remote Vineyard & $1.36 * * *(3.98)$ & $1.41 * * *(4.31)$ & $1.29 * * *(3.80)$ \\
\hline$\gamma_{1}$ & $8.48(0.35)$ & $-13.63 * * *(-11.65)$ & $-11.84 * * *(-11.60)$ \\
\hline$\gamma_{2}$ & $9.98(0.41)$ & $-12.19 * * *(-11.06)$ & $-10.38 * * *(-11.00)$ \\
\hline$\gamma_{3}$ & $10.80(0.45)$ & $-11.38 * * *(-10.81)$ & $-9.56 * * *(-10.73)$ \\
\hline$\gamma_{4}$ & $11.97(0.50)$ & $-10.31 * * *(-10.06)$ & $-8.46 * * *(-9.83)$ \\
\hline$\gamma_{5}$ & $13.05(0.54)$ & $-9.34 * * *(-9.34)$ & $-7.47 * * *(-8.96)$ \\
\hline$\gamma_{6}$ & $14.65(0.61)$ & $-7.846 * * *(-8.28)$ & $-5.926 * * *(-7.59)$ \\
\hline$\gamma_{7}$ & $16.81(0.70)$ & $-5.782 * * *(-6.56)$ & $-3.826 * * *(-5.31)$ \\
\hline Log Likelihood & -376.0 & -397.3 & -393.5 \\
\hline Pseudo R2 (in \%) & 39.7 & 36.3 & 36.9 \\
\hline
\end{tabular}


Table 6

\section{Prediction and Deviation by Rank}

\begin{tabular}{l|cccccccc|c}
\hline \multirow{2}{*}{ Rank } & \multicolumn{7}{|c|}{ Deviation by number of ranks } & \\
& 0 & 1 & 2 & 3 & 4 & 5 & 6 & 7 & Sum \\
\hline 1 & 0 & 0 & 1 & 0 & 0 & 0 & 0 & 0 & 1 \\
2 & 5 & 0 & 4 & 1 & 1 & 0 & 0 & - & 11 \\
3 & 0 & 19 & 3 & 1 & 0 & 0 & - & - & 23 \\
4 & 33 & 20 & 6 & 0 & 0 & - & - & - & 59 \\
5 & 24 & 35 & 4 & 0 & 0 & - & - & - & 63 \\
6 & 54 & 28 & 3 & 0 & 0 & 0 & - & - & 85 \\
7 & 41 & 28 & 0 & 0 & 0 & 0 & 0 & - & 69 \\
8 & 18 & 15 & 0 & 0 & 0 & 0 & 0 & 0 & 33 \\
\hline Sum & 175 & 145 & 21 & 2 & 1 & 0 & 0 & 0 & 344 \\
In \% & 50.9 & 42.2 & 6.1 & 0.6 & 0.3 & 0.0 & 0.0 & 0.0 & 100.0 \\
\hline
\end{tabular}

Own calculations. 
Table 7

Marginal Effects of Model Using Fall Solar Radiation

\begin{tabular}{|c|c|c|c|c|c|c|c|c|}
\hline & \multirow[b]{2}{*}{ Rank 1} & \multirow[b]{2}{*}{ Rank 2} & \multirow[b]{2}{*}{ Rank 3} & \multicolumn{2}{|c|}{ Probability (in \%) } & \multirow[b]{2}{*}{ Rank 6} & \multirow[b]{2}{*}{ Rank 7} & \multirow[b]{2}{*}{ Rank 8} \\
\hline & & & & Rank 4 & Rank 5 & & & \\
\hline Baseline & 0.27 & 3.32 & 6.52 & 16.79 & 18.95 & 24.61 & 19.65 & 9.74 \\
\hline & \multicolumn{8}{|c|}{ Change in Probability (in \%) } \\
\hline \multicolumn{9}{|l|}{$\begin{array}{l}\text { Continuous } \\
\text { Variables }^{1}\end{array}$} \\
\hline Fall Energy & 1.19 & 5.96 & 5.17 & 3.35 & -2.07 & -5.06 & -5.45 & -3.09 \\
\hline Depth of Soil & -0.02 & -0.25 & -0.44 & -0.71 & -0.21 & 0.24 & 0.60 & 0.78 \\
\hline Altitude ${ }^{a}$ & -0.02 & -0.24 & -0.34 & -0.44 & -0.04 & 0.32 & 0.42 & 0.36 \\
\hline Vineyard Size & -0.01 & -0.08 & -0.12 & -0.19 & -0.04 & 0.23 & 0.05 & 0.15 \\
\hline \multicolumn{9}{|l|}{ Dummy Variables ${ }^{2}$} \\
\hline Clay Slate & 4.46 & 14.90 & 9.68 & 7.42 & -0.38 & -9.69 & -15.92 & -10.48 \\
\hline Weathered Slate & 1.85 & 6.02 & 5.98 & 8.31 & 2.46 & -5.36 & -10.60 & -8.66 \\
\hline Slate Quartzite & 0.56 & 3.41 & 3.59 & 3.30 & -0.65 & -3.27 & -3.91 & -3.04 \\
\hline Sand & -0.26 & -2.87 & -4.83 & -9.13 & -4.14 & 4.38 & 8.60 & 8.26 \\
\hline Clay, Loam & -0.24 & -2.67 & -4.44 & -7.78 & -2.82 & 4.17 & 8.13 & 5.65 \\
\hline Quartzite & -0.23 & -2.44 & -3.99 & -7.01 & -2.35 & 3.99 & 6.29 & 5.74 \\
\hline Remote & -0.26 & -3.13 & -5.64 & -11.66 & -6.44 & 5.29 & 10.99 & 10.86 \\
\hline
\end{tabular}


Table 8

Global Warming and Vineyard Ranking

\begin{tabular}{|c|c|c|c|c|c|c|c|c|c|}
\hline & & \multicolumn{8}{|c|}{ Probability (in \%) } \\
\hline & & Rank & $\begin{array}{c}\text { Rank } \\
2\end{array}$ & $\begin{array}{c}\text { Rank } \\
3\end{array}$ & $\underset{4}{\operatorname{Rank}}$ & $\underset{5}{\operatorname{Rank}}$ & $\begin{array}{c}\text { Rank } \\
6\end{array}$ & Rank & $\begin{array}{c}\text { Rank } \\
8\end{array}$ \\
\hline \multirow{2}{*}{\multicolumn{2}{|c|}{ Baseline }} & 0.27 & 3.32 & 6.52 & 16.79 & 18.95 & 24.61 & 19.65 & 9.74 \\
\hline & & \multicolumn{8}{|c|}{ Change in Probability (in \%) } \\
\hline \multicolumn{10}{|c|}{$\begin{aligned} \text { temperature } & \text { energy increase } \\
\text { increase } & (\mathrm{MJ} / \text { month })\end{aligned}$} \\
\hline $1^{\circ} \mathrm{C}$ & 47.43 & 0.32 & 2.19 & 2.46 & 2.45 & -0.29 & -2.21 & -2.79 & -2.13 \\
\hline $2^{\circ} \mathrm{C}$ & 94.87 & 0.95 & 5.21 & 4.95 & 3.88 & -1.23 & -4.50 & -5.44 & -3.82 \\
\hline $3^{\circ} \mathrm{C}$ & 142.82 & 2.06 & 9.02 & 7.10 & 4.22 & -2.54 & -6.80 & -7.93 & -5.24 \\
\hline \multirow{2}{*}{\multicolumn{2}{|c|}{ Baseline }} & \multicolumn{8}{|c|}{ Number of Vineyards } \\
\hline & & \multicolumn{8}{|c|}{$\begin{array}{cc}\text { Number of Vineyards } \\
79\end{array} 64$} \\
\hline \multicolumn{2}{|r|}{$1^{\circ} \mathrm{C}$ increase } & 0 & 13 & 5 & 111 & 43 & 91 & 62 & 19 \\
\hline \multicolumn{2}{|r|}{$2^{\circ} \mathrm{C}$ increase } & 0 & 30 & 11 & 121 & 37 & 83 & 47 & 15 \\
\hline \multicolumn{2}{|r|}{$3^{\circ} \mathrm{C}$ increase } & 2 & 56 & 10 & 115 & 39 & 73 & 36 & 13 \\
\hline
\end{tabular}


Table 9

Global Warming and Land Values

in 2003 prices

\begin{tabular}{|c|r|r|r|r|}
\hline & \multicolumn{1}{|c|}{ Baseline } & Simulation $1^{\circ} \mathrm{C}$ & Simulation $2^{\circ} \mathrm{C}$ & Simulation $3{ }^{\circ} \mathrm{C}$ \\
\hline & & & & \\
\hline Hectares & & & & \\
\hline Rank 1 & 0.0 & 0.0 & 0.0 & 7.8 \\
\hline Rank 2 & 19.3 & 71.1 & 375.5 & 851.6 \\
\hline Rank 3 & 10.8 & 32.1 & 212.8 & 134.6 \\
\hline Rank 4 & 1283.4 & 1958.2 & 2317.2 & 2338.0 \\
\hline Rank 5 & 1365.5 & 995.8 & 965.2 & 1086.4 \\
\hline Rank 6 & 2384.9 & 2640.6 & 2582.7 & 2366.2 \\
\hline Rank 7 & 2851.1 & 2431.9 & 1843.7 & 1550.5 \\
\hline Rank 8 & 1134.6 & 919.9 & 752.5 & 714.5 \\
\hline Total & 9049.6 & 9049.6 & 9049.6 & 9049.6 \\
\hline & & & & 467.4 \\
\hline Value in Mill $€$ & 231.3 & 276.1 & 371.0 & \\
\hline & & & & \\
\hline
\end{tabular}




\section{Figure 1}

Solar Radiation by Latitude

on a horizontal surface in the northern hemisphere

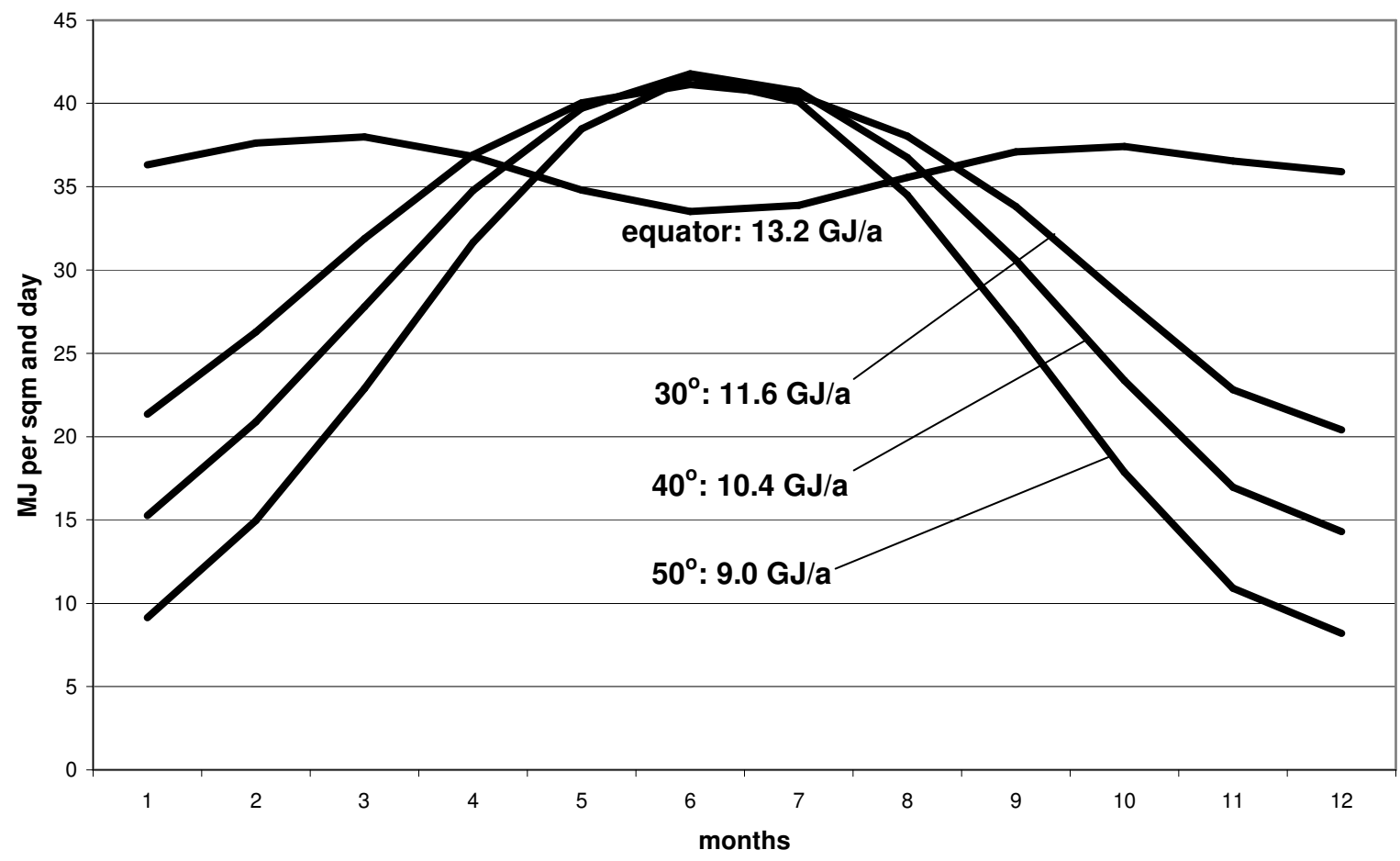


Figure 2

Solar Radiation by Inclination

on a southwards oriented surface in Trier (49.8 ${ }^{\circ}$ north)

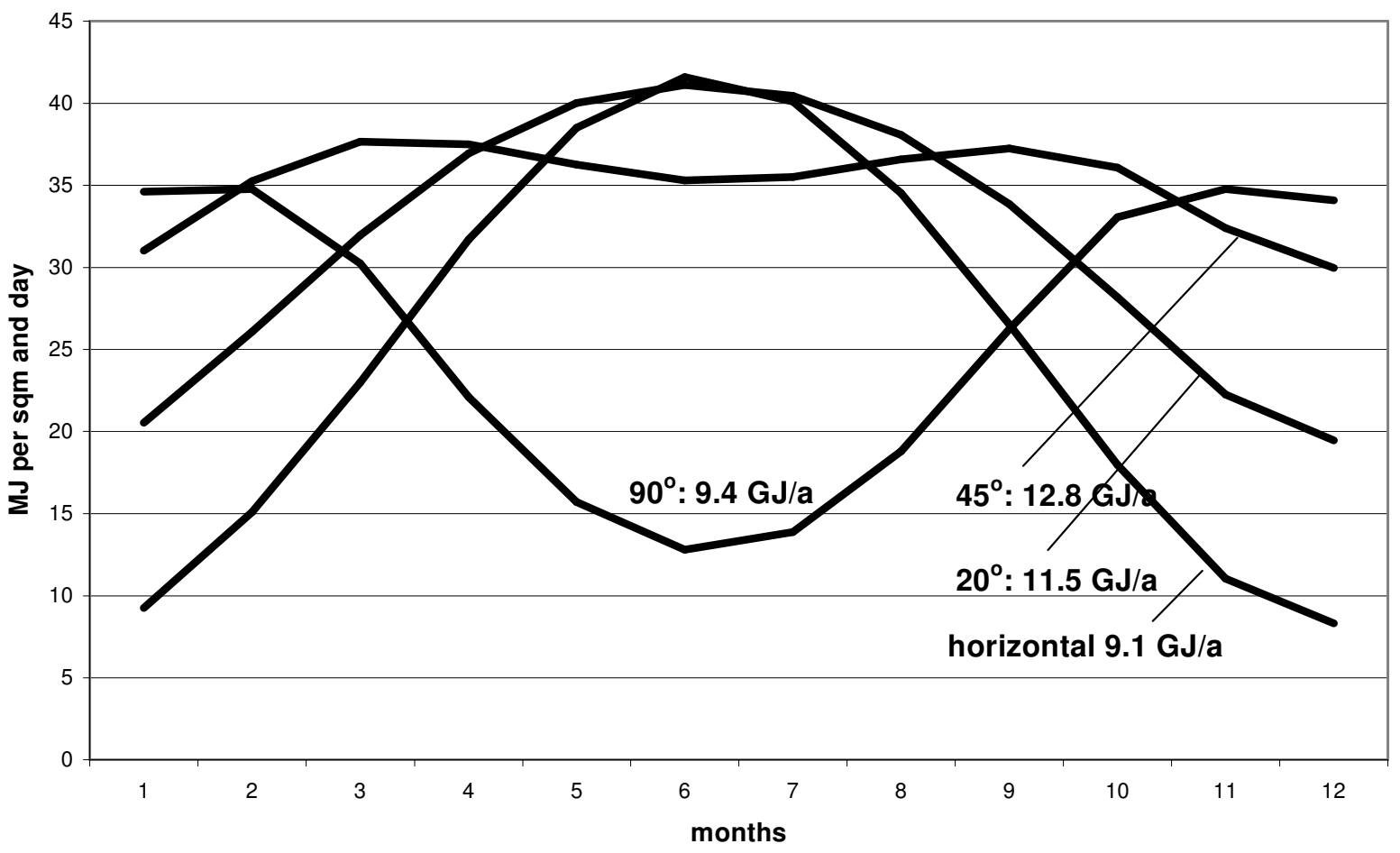




\section{Figure 3}

\section{Solar Radiation by Orientation}

on a $45^{\circ}$ tilted surface in Trier $\left(49.8^{\circ}\right.$ north)

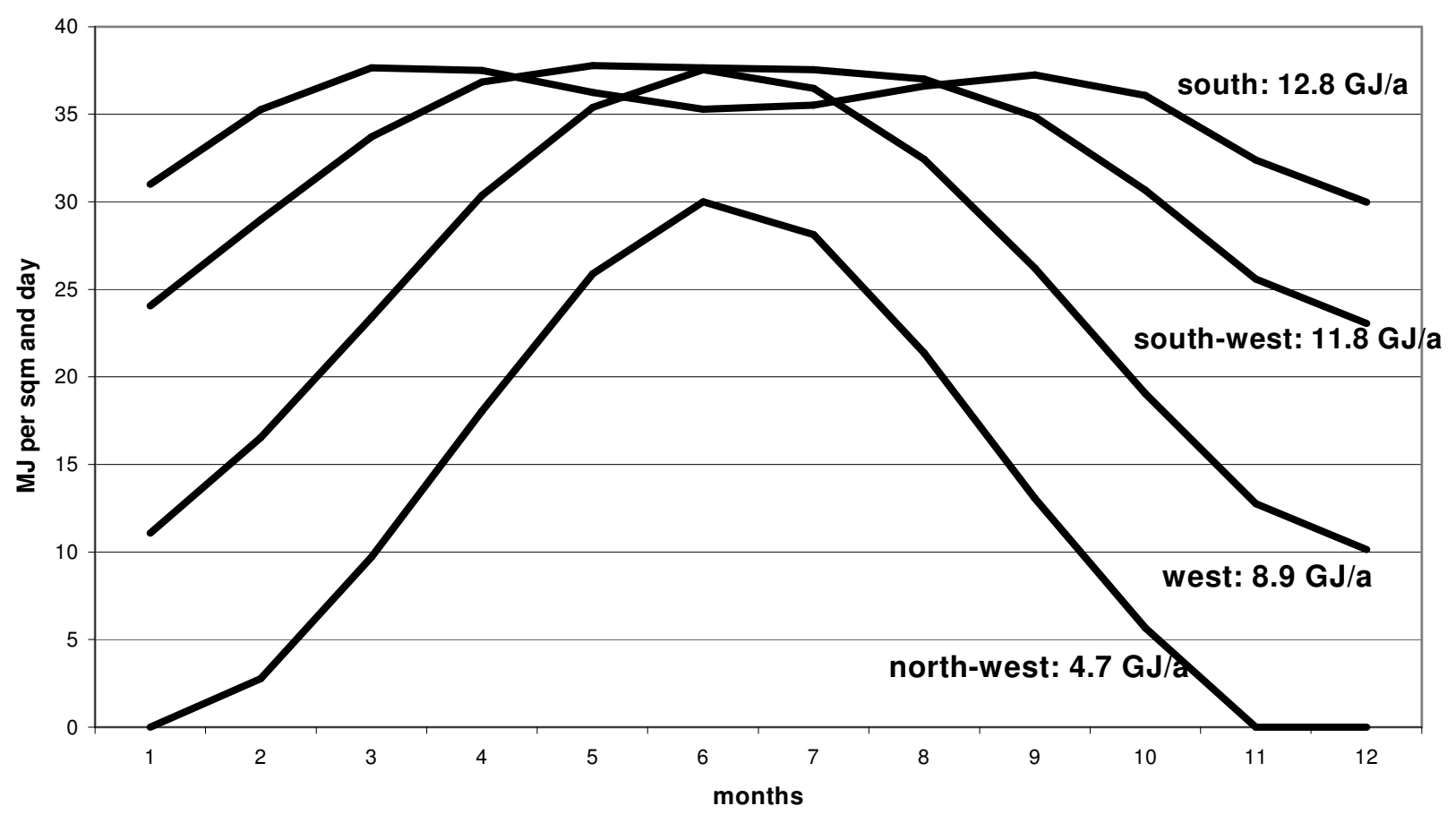


Figure 4

Solar radiation and temperature

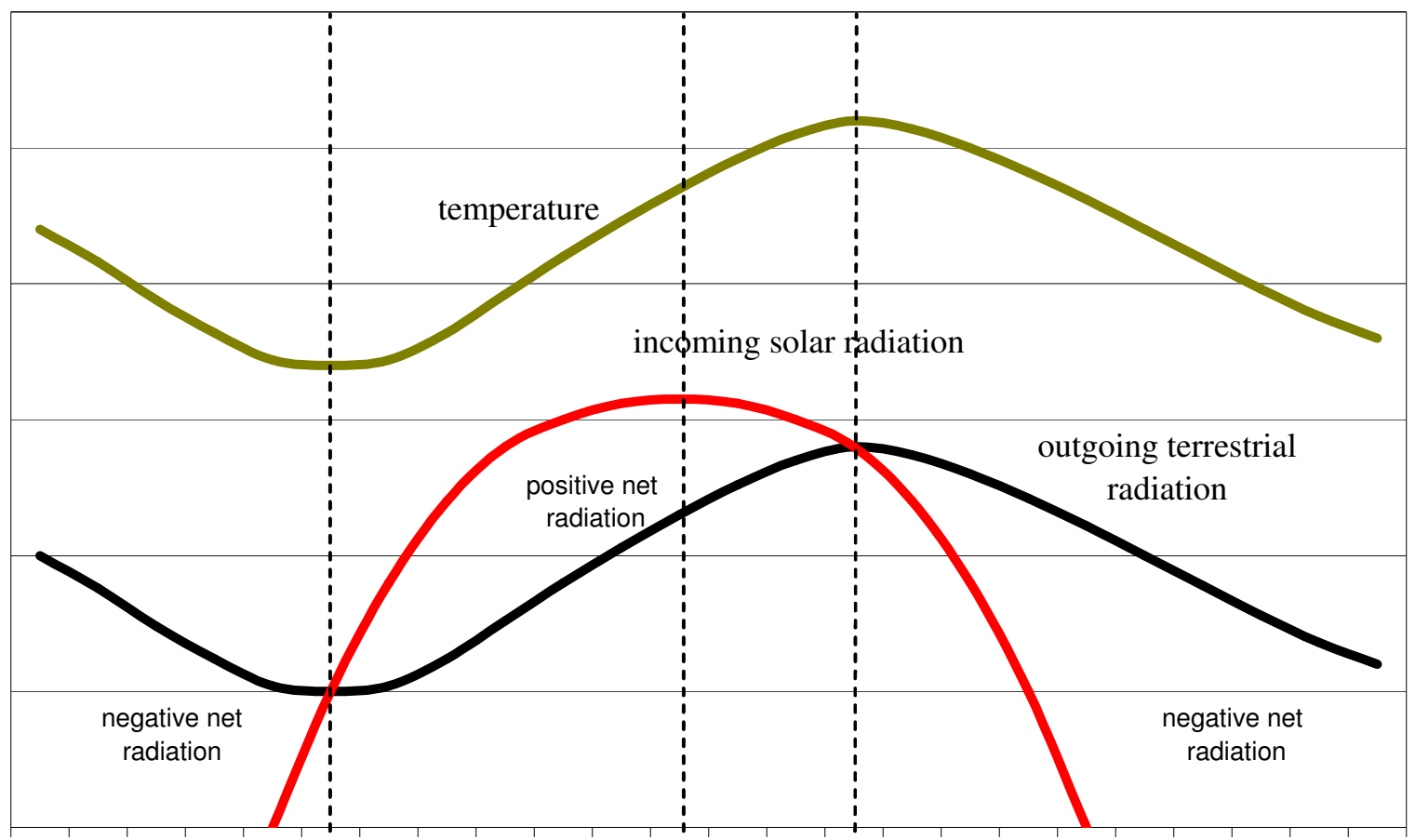

$\begin{array}{llllllllllllllllllllllll}1 & 2 & 3 & 4 & 5 & 6 & 7 & 8 & 9 & 10 & 11 & 12 & 13 & 14 & 15 & 16 & 17 & 18 & 19 & 20 & 21 & 22 & 23 & 24\end{array}$ 